\title{
PHYSIOLOGICAL DISTURBANCES DURING EXPERIMENTAL DIPHTHERITIC INTOXICATION. III. RESPIRATORY QUOTIENTS AND METABOLIC RATE ${ }^{1}$
}

\author{
By HERMAN YANNET AND WALTER GOLDFARB \\ (From the Department of Pediatrics and Physiology, Yale University School of \\ Medicine, New Haven)
}

(Received for publication May 20, 1933)

Previous investigators have demonstrated disturbances of carbohydrate metabolism during both clinical and experimental diphtheritic intoxication. These disturbances are made manifest by delayed sugar tolerance curves, high blood sugar values, and, occasionally, glycosuria. These observations have led to the assumption on the part of many that, during the course of diphtheria, there exists a relative insulin deficiency or dysfunction; a detailed review of this phase of the literature is given in Paper I of this series (1). In the two preceding papers of this series $(1,7)$ we have demonstrated by histological and chemical studies, a widespread destruction of liver parenchyma with derangement of liver function following the intravenous injection of diphtheria toxin in rabbits. Physiologically, this manifested itself by varying degrees of disturbance in hepatic glyconeogenesis and hepatic glycogenesis. The belief was expressed that the above mentioned disturbances in carbohydrate metabolism could be related to the hepatic injury. In the following communication are reported the results of a study of the respiratory quotients in rabbits, aimed to determine what effect, if any, diphtheritic intoxication has upon their ability to burn carbohydrates.

\section{METHOD}

The apparatus used for the determination of respiratory quotients was described by Marine (2) in 1922, and is based on the Haldane open-circuit system. It was adequately tested before the experiments were begun for proper absorption of carbon dioxide and water and for air-tight connections.

Rabbits in good condition, and weighing from 900 to 1400 grams were employed for the investigation. Both control and diphtheritic animals were deprived of food 24 hours before the onset of the experiment. Starvation was maintained throughout the balance of the experiment, only water being offered. The diphtheria toxin used was of a strength such that $0.016 \mathrm{cc}$. was equivalent to 1 minimal lethal dose of toxin. Three-quarters to 1 minimal lethal dose was injected intravenously. It was previously found that this dose would bring about the death of the fasted animals in from three to seven days. The animals pany.

1 This work was aided by a grant from The Corn Products Refining Com- 
were placed in the respiratory chamber for approximately two hour periods daily until a fatal termination seemed imminent. No determinations were carried out on moribund animals. The rabbits adjusted themselves to the chamber readily and although there was slight movement, the degree of activity was exceedingly small and approximately comparable in both experimental and control animals. Since urinary nitrogen was not determined the results are expressed as total respiratory quotients, and the calories produced, as total metabolic rate.

\section{RESULTS}

The results are presented in Table I. For comparative purposes the respiratory quotients obtained after similar periods of fasting have been

TABLE I

Results of metabolism studies on normal and diphtheritic rabbits on a fasting regime

\begin{tabular}{|c|c|c|c|c|c|c|c|c|c|c|}
\hline \multicolumn{5}{|c|}{ Normal } & \multicolumn{6}{|c|}{ Diphtheritic } \\
\hline $\begin{array}{c}\text { Experi- } \\
\text { ment } \\
\text { number }\end{array}$ & $\begin{array}{c}\text { Hours } \\
\text { starved }\end{array}$ & Weight & $\begin{array}{c}\text { Respira- } \\
\text { tory } \\
\text { quotient }\end{array}$ & $\begin{array}{c}\text { Total } \\
\text { meta- } \\
\text { bolic } \\
\text { rate }\end{array}$ & $\begin{array}{c}\text { Experi- } \\
\text { ment } \\
\text { number }\end{array}$ & $\begin{array}{c}\text { Hours } \\
\text { to } \\
\text { death }\end{array}$ & $\begin{array}{c}\text { Hours } \\
\text { starved }\end{array}$ & Weight & $\begin{array}{c}\text { Respira- } \\
\text { tory } \\
\text { quotient }\end{array}$ & $\begin{array}{l}\text { Total } \\
\text { meta- } \\
\text { bolic } \\
\text { rate }\end{array}$ \\
\hline \multirow{4}{*}{1.} & & grams & & $*$ & \multirow{4}{*}{6.} & & & grams & & $*$ \\
\hline & 72 & 865 & .70 & 4.52 & & 112 & 48 & 1256 & .79 & 3.79 \\
\hline & 96 & 786 & .75 & 4.72 & & 64 & 96 & 1093 & .79 & 3.95 \\
\hline & & & & & & 40 & 120 & 1040 & .82 & 3.68 \\
\hline \multirow[t]{4}{*}{2.} & 48 & 1042 & .80 & 4.89 & \multirow{4}{*}{7.} & & & & & \\
\hline & 72 & 922 & .75 & 4.90 & & 66 & 24 & 1319 & .76 & 3.34 \\
\hline & 96 & 914 & .79 & 4.54 & & 40 & 42 & 1290 & .83 & 3.15 \\
\hline & & & & & & 12 & 68 & 1230 & .78 & 3.24 \\
\hline \multirow[t]{3}{*}{3.} & 24 & 1495 & .87 & 3.51 & \multirow{3}{*}{8.} & & & & & \\
\hline & 48 & 1415 & .81 & 3.66 & & 30 & 72 & 1077 & .81 & 3.11 \\
\hline & & & & & & 8 & 96 & 1030 & .80 & 3.28 \\
\hline \multirow[t]{7}{*}{4.} & 12 & 969 & .98 & 3.36 & \multirow{4}{*}{9.} & & & & & \\
\hline & 36 & 929 & .80 & 3.52 & & 152 & 24 & 1368 & .86 & 4.00 \\
\hline & 60 & 859 & .81 & 3.45 & & 128 & 48 & 1323 & .78 & 4.07 \\
\hline & 84 & 813 & .82 & 3.30 & & 8 & 168 & 1045 & .74 & 3.90 \\
\hline & 108 & 780 & .72 & 3.25 & & & & & & \\
\hline & 132 & 750 & .73 & 3.78 & 10. & 44 & 48 & 970 & .78 & 2.92 \\
\hline & & & & & & 15 & 72 & 870 & .76 & 3.15 \\
\hline \multirow[t]{4}{*}{5.} & 28 & 1210 & .85 & 3.91 & & & & & & \\
\hline & 52 & 1110 & .84 & 3.58 & 11. & 26 & 30 & 1179 & .84 & 3.93 \\
\hline & 76 & 1095 & .78 & 3.20 & & & & & & \\
\hline & 114 & 967 & .80 & 3.27 & 12. & 24 & 24 & 1349 & .76 & 4.17 \\
\hline
\end{tabular}

* Total metabolic rate was obtained by dividing the total calories per hour by the weight in kgms. raised to the $2 / 3$ power.

averaged and assembled in Table II. Although we have been interested primarily in the question involving the ability of the diphtheritic animal to burn carbohydrates, the data for the total metabolic rates have also been included. These values are expressed as calories per hour per unit of surface area, the latter value being obtained by raising the weight in kilograms to the two-thirds power. This result should be multiplied by a constant, 
TABLE II

Average respiratory quotients obtained in normal and diphtheritic rabbits after different periods of fasting

\begin{tabular}{c|c|c|c|c}
\hline \hline \multirow{2}{*}{$\begin{array}{c}\text { Hours of } \\
\text { starvation }\end{array}$} & \multicolumn{2}{|c|}{ Diphtheritic } & \multicolumn{2}{|c}{ Normal } \\
\cline { 2 - 5 } & $\begin{array}{c}\text { Average respira- } \\
\text { tory quotient }\end{array}$ & $\begin{array}{c}\text { Number of } \\
\text { observations }\end{array}$ & $\begin{array}{c}\text { Average respira- } \\
\text { tory quotient }\end{array}$ & $\begin{array}{c}\text { Number of } \\
\text { observations }\end{array}$ \\
\hline 24 & .81 & 4 & .84 & 3 \\
48 & .80 & 4 & .82 & 4 \\
72 & .78 & 3 & .76 & 4 \\
96 & .80 & 2 & .76 & 5 \\
$120+$ & .78 & 2 & .73 & 1 \\
\hline
\end{tabular}

to make the values express surface area in the ordinary units. The omission of this procedure still allows comparison of the various animals in terms analogous to those which would be obtained with a more exact formula for surface area.

The respiratory quotients determined during the course of the intoxication do not suggest any gross interference with the burning of carbohydrates. It can be seen that after the development of a fasting status the respiratory quotients tend to remain with only slight exceptions at a fairly constant level, which averages between .78 and .80 , a level well above that to be expected had there been any severe degree of insulin dysfunction.

In Table II the respiratory quotients obtained on the diphtheritic animals after similar periods of fasting have been averaged and compared with those obtained on the normal controls. The lack of any striking difference between the two sets of values is apparent.

It might be mentioned, in passing, that no great change was noted in the total metabolic rate as the intoxication progressed. In other words, diphtheria toxin when injected into rabbits does not exhibit any calorigenic activity.

\section{DISCUSSION}

Essentially the same approach for the investigation of the disturbance in carbohydrate metabolism during diphtheria has been utilized previously by Josephs (3), Hector (4) and Arloing and Laulanie (5).

Josephs determined the respiratory quotients in dogs by collection of the expired air over periods of from three to five minutes, followed by analysis of a sample in a Haldane gas apparatus. The results of four experiments were described. From the data presented it is evident that there was no difficulty in the oxidation of carbohydrates, the nonprotein respiratory quotients remaining about 0.80 throughout the course of the investigation. The dogs were subjected to only a mild degree of intoxication as evidenced by the relatively low blood nonprotein nitrogen levels and the prolonged periods of survival. 
Arloing and Laulanie in 1895 studied the respiratory exchange by means of closed calorimetry in rabbits following the injection of large doses of toxin subcutaneously (death occurred in from 6 to 36 hours). Because of the overwhelming nature of the intoxication it is difficult to interpret the results. Furthermore there was no suitable dietary control previous to the experiment. Respiratory quotients ranging from 0.90 to 0.70 were obtained. A tendency for a slight rise to occur during the first six to eight hours following the injection of toxin was noted.

Hector in 1926 studied the respiratory quotients in six cases of diphtheria of varying degrees of severity, using a Fridericia apparatus. $\mathrm{He}$ determined the respiratory quotient at frequent intervals following the administration of glucose by mouth. From his results he concluded that there was no evidence of any inability to oxidize carbohydrates during the course of diphtheria.

J. A. Johnston (6) has recently acquainted us with data similar to Hector's, on a diphtheria patient with severe myocardial involvement. The observations, made on the $22 \mathrm{~d}$ day of the disease, showed that the respiratory quotients following the intravenous administration of 20 grams of glucose rose from the pre-injection level of 0.84 to 0.90 at one hour and fell to 0.85 and 0.77 at the second and third hours respectively. Comparing this with similar studies on normal children, Johnston interprets these results to signify an adequate response to the injected glucose. These observations were made too late in the disease to be strictly comparable to our experimental results. Similar studies, both early and late in the disease, would be valuable, especially if accompanied by observations of the blood nonprotein nitrogen, which seems to be the best objective measure of the severity of the intoxication.

In Paper IV of this series (8), the results of the investigation of the serum electrolytes during diphtheritic intoxication in rabbits will be presented. These studies demonstrate the frequent occurrence of a decrease in serum bicarbonate, chloride and sodium. It is apparent that the development of acidosis while in the respiratory chamber would increase the respiratory quotient. However, it is not likely that any marked change occurred during the relatively short period of observation. Furthermore, it is unlikely that low respiratory quotients were so masked by developing acidosis as to bring about the substantial agreement in the respiratory quotients found in our experiments.

The criticism which may be made of the work reviewed above, as well as of our experiments, is that by this type of investigation one can adequately demonstrate only severe grades of interference with carbohydrate oxidation. The failure to find any evidence of this disability would, therefore, not preclude minor degrees of insulin insufficiency or dysfunction. We believe this to be a just criticism and have duly considered it in framing our conclusions. 


\section{SUMMARY AND CONCLUSION}

1. Study of the respiratory quotients of rabbits during the course of diphtheritic intoxication produced by the intravenous injection of diphtheria toxin reveals no evidence of any gross disturbance in the oxidation of carbohydrates.

2. It was not possible to demonstrate any significant changes in the total metabolic rate during the course of the intoxication.

\section{BIBLIOGRAPHY}

1. Yannet, H., and Darrow, D. C., J. Clin. Invest., 1933, xii, 767. Physiological Disturbances during Experimental Diphtheritic Intoxication. I. Blood Sugar, Lactic Acid and Nonprotein and Amino-acid Nitrogen.

2. Marine, D. M., J. Metab. Research, 1922, ii, 29. A Modified Haldane Open Circuit Apparatus for Measuring the Respiratory Exchange in New Born Babies and also in Rabbits and Cats.

3. Josephs, H. W., Bull. Johns Hopkins Hosp., 1927, xli, 400. The Metabolism Following Injection of Diphtheria Toxin in Dogs.

4. Hector, F. J., Lancet, 1926, ii, 642. Carbohydrate Metabolism in Diphtheria.

5. Arloing, S., and Laulanie, F., Arch. de physiol. norm. et path., 1895, vii, 675. Introduction à la étude des troubles de le température des combustions respiratoires et de la thermogénèse sous l'influence des toxines bactériennes.

6. Johnston, J. A., Personal communication.

7. Yannet, H., and Darrow, D. C., J. Clin. Invest., 1933, xii, 779. Physiological Disturbances during Experimental Diphtheritic Intoxication. II. Hepatic Glycogenesis and Glycogen Concentration of Cardiac and Skeletal Muscle.

8. Darrow, D. C., Yannet, H., and Cary, M. Katharine (To be published). Physiological Disturbances during Experimental Diphtheritic Intoxication. IV. Blood Electrolytes and Hemoglobin Concentrations. 